\title{
PENGARUH PENERAPAN PENDEKATAN PEMBELAJARAN KONTEKSTUAL TERHADAP HASIL BELAJAR MATEMATIKA MURID SEKOLAH DASAR DI KOTA MAKASSAR
}

\author{
Ira Irviana \\ Prodi PGSD, Universitas Islam Makassar \\ e-mail: irairviana90@yahoo.com
}

\begin{abstract}
Abstrak. Tujuan penelitian ini adalah (i) Untuk mengetahui gambaran hasil belajar matematika murid SD Inpres BTN IKIP 1 Makassar (ii) Untuk mengetahui gambaran penerapan pendekatan kontekstual dalam pembelajaran matematika di kelas IV SD Inpres BTN IKIP 1 Makassar (iii) Untuk mengetahui pengaruh penerapan pendekatan kontekstual terhadap hasil belajar matematika murid di SD Inpres BTN IKIP 1 Makassar. Penelitian ini adalah jenis penelitian true experiment (experiment penuh). Penelitian ini dirancang untuk mendapatkan pengaruh penerapan pembelajaran kontekstual terhadap hasil belajar murid. Desain penelitian eksperimen yang digunakan adalah pretestposttest control group design didasarkan pada Sugiono (2010), yang melibatkan dua kelompok yaitu satu kelompok sebagai kelompok kontrol dan satu sebagai kelompok eksperimen yang dipilih secara random kemudian diberikan pretest untuk mengetahui keadaan awal. Dalam kelompok eksperimen dilakukan dengan menggunakan penerapan pembelajaran kontekstual pada murid kelas IV SD BTN IKIP I Makassar. Dalam kelas kontrol pembelajaran dilakukan di dalam ruang kelas dengan menggunakan metode pembelajaran konvensional dengan media pembelajaran berupa literatur tentang materi matematika dan lembar kegiatan murid. Setelah diberikan perlakuan pendekatan kontekstual, hasil belajar siswa mengalami peningkatan.
\end{abstract}

Kata Kunci: Pendekatan Pembelajaran Kontekstual; Hasil Belajar Matematika.

\section{PENDAHULUAN}

Dalam Proses pembelajaran matematika, seorang guru memiliki peran penting dalam menyampaikan informasi, melatih keterampilan dan membimbing belajar murid sehingga para guru dituntut memiliki kualifikasi dan kompetensi tertentu, agar proses belajar dan pembelajaran dapat berlangsung efektif dan efisien. Berdasarkan hasil observasi bagi kebanyakan murid mengalami kesulitan dalam mengaplikasikan matematika kedalam situasi kehidupan real. Hal lain yang menyebabkan sulitnya matematika karena kurang begitu bemakna. Bila murid belajar matematika terpisah dari pengalaman sehari-hari maka murid akan cepat lupa dan tidak dapat mengaplikasikan matematika. dikenal hanya sebagai pengajar sekarang menjadi partner murid.

Melalui penerapan metode kontekstual dan reposisi peran guru dan murid dalam pembelajaran, maka kegiatan pembelajaran itu akan menjadi efektif sehingga dapat mencapai tujuan pembelajaran yang diharapkan yaitu meningkatkan kualitas pembelajaran dan prestasi murid. Ahmad Munif (2003 : 4) mengatakan bahwa :

sekolah dikatakan efektif bilamana proses pembelajaran dapat mencapai tujuan yang ditetapkan dengan baik yang berimplikasi pada upaya guru dalam mengembangkan system 
pembelajaran secara profesional berdasarkan kurikulum yang ditetapkan.

Belajar matematika bagi para murid merupakan alat untuk memahami atau menyampaikan suatu informasi misalnya melalui persamaan-persamaan, atau tabel-tabel dalam pembelajaran matematika. Belajar matematika adalah pembentukan pola piker dalam pemahaman suatu pengertian maupun penalaran dalam suatu hubungan. Matematika berasal dari bahasa Yunani atau Latin "Thanein" atau "Mathein" yang artinya belajar atau hal yang dipelajari, sedangkan dalam bahasa Belanda disebut "Wiskunde" atau ilmu pasti yang semuanya berkaitan dengan penalaran (Depdiknas, 2006: 2).

Ruseffendi (Tim MKPBM, 2001 : 18) menyatakan bahwa "Matematika terbentuk sebagai hasil pemikiran manusia yang berhubungan dengan ide, proses, dan penalaran". Tahap awal matematika terbentuk dari pengalaman manusia dalam dunianya secara empiris, karena matematika sebagai aktifitas manusia. Kemudian pengalaman itu diproses, diolah secara analisis dan sintesis dengan penalaran di dalam pola pikir kognitif sehingga sampai pada suatu kesimpulan berupa konsep matematika.

Karso (2007 : 1.4) menyatakan bahwa "Matematika adalah ilmu yang deduktif, aksiomatik, formal, hirarkis, abstrak, bahasa simbol yang padat arti dan semacamnya". Ruseffendi (Tim MKPBM, 2001 : 24) menyatakan bahwa "Setiap konsep yang abstrak dalam matematika yang baru dipahami segera diberi penguatan supaya mengendap, melekat dan tahan lama tertanam dalam diri anak sehingga menjadi miliknya dalam pola pikir maupun tindakannya. Dalam setiap pembelajaran matematika hendaknya dimulai dengan pengenalan masalah yang sesuai dengan situasi (contextual problem). Dengan mengajukan masalah kontekstual secara bertahap dibimbing untuk menguasai konsep matematika. Untuk meningkatkan keaktifan pembelajaran maka dituntut untuk menggunakan alat atau media pembelajaran yang dapat membantu proses dan keberhasilan pembelajaran salah satunya dengan pendektan kontekstual.
Menurut Elaine B. Johnson pembelajaran kontekstual adalah sebuah proses pendidikan yang membantu para murid melihat makna di dalam materi yang mereka pelajari dengan menghubungkan subjek-subjek akademik dengan konteks dalam kehidupan sehari-hari. Menurut Muhammad Muchlis Solichin pembelajaran kontekstual merupakan konsepsi pembelajaran yang membantu guru menghubungkan mata pelajaran dengan situasi dunia nyata dan pembelajaran yang memotivasi murid agar menghubungkan pengetahuan dengan kehidupan sehari-hari sebagai anggota keluarga dan masyarakat.

Menurut hemat penulis, pembelajaran kontekstual adalah sebuah pembelajaran dimana seorang guru mengaitkan materi pembelajaran dengan realitas kehidupan peserta didik dan memotivasi murid untuk mendapatkan jawaban dari pertanyaanpertanyaan dengan caranya sendiri sehingga pengetahuan yang ia dapatkan lebih bermakna dan dapat diimplementasikan dalam kehidupan sehari-hari. Dengan konsep ini, hasil pembelajaran diharapkan lebih bermakna bagi murid. Proses berlangsung secara alamiah dalam bentuk kegiatan murid bekerja dan mengalami, bukan mentransfer pengetahuan dari guru ke murid. Strategi pembelajaran lebih dipentingkan daripada hasil.

Menurut Elaine B.Johnson (2007:19) pendekatan pembelajaran merupakan kegiatan yang dipilih yang dapat memberikan fasilitas atau bantuan kepada peserta didik untuk mencapai tujuan pembelajaran.

Menurut Hamruni (2011), terdapat lima karakteristik penting dalam proses pembelajaran kontekstual, yaitu:

a) Pembelajaran merupakan proses pengaktifan pengetahuan yang sudah ada (activating knowledge) artinya sesuatu yang akan dipelajari tidak terlepas dari pengetahuan yang sudah dipelajari. Dengan demikian, pengetahuan yang akan diperoleh murid adalah pengetahuan yang utuh yang memiliki keterkaitan satu sama yang lain.

b) Pembelajaran yang dapat menambah pengetahuan baru (acquiring knowledge).

c) Pengetahuanan baru itu diperoleh dengan cara deduktif, artinya pembelajaran dimulai dengan cara mempelajari secara 
keseluruhan, kemudian memperhatikan secara detail.

d) Memahami pengetahuan (understanding knowledge). Artinya pengetahuan yang diperoleh bukan untuk dihafal tetapi untuk dipahami dan diyakini kemudian dikaitkan dengan realitas kehidupan sehari-hari agar dapat dipraktikkan dan menjadi kebiasaan.

e) Mempraktikkan pengetahuan dan pengalaman tersebut (applying knowledge). Artinya pengetahuan dan pengalaman yang diperoleh harus dapat diimplementasikan dalam kehidupan murid, sehingga tampak perubahan perilaku murid.

f) Melakukan refleksi (reflecting knowledge) terhadap strategi pengembangan pengetahuan. Hal ini sebagai umpan balik (feedback) untuk proses perbaikan dan penyempurnaan strategi.

\section{METODE}

Penelitian ini adalah jenis penelitian true experiment (experiment penuh). Penelitian ini dirancang untuk mendapatkan pengaruh penerapan pembelajaran kontekstual terhadap hasil belajar murid. A. Muri Yusuf (2014: 30) True experiment adalah suatu jenis penelitian yang sesungguhnya, dimana peneliti mengotrol variabelvariabel yang diteliti dengan baik serta mengendalikan situasi penelitian dari ancaman yang mungkin merusak penelitian dari keadaan yang sesungguhnya. Ini berarti bahwa dalam eksperimen yang sesungguhnya, validitas internal dan eksternal merupakan kondisi utama yang perlu mendapat perhatian oleh peneliti dalam menata rancangan penelitian yang dilakukan. Menurut Sugiyono (2010: 112) menyatakan bahwa true experimental (eksperimen yang betulbetul) desain ini peneliti dapat mengotrol semua variabel luar yang mempengaruhi jalannya eksperimen.
Pengambilan sampel dilakukan dengan teknik acak, acak digunakan untuk penentuan sampel kelompok eksperimen dan kelompok kontrol begitu juga pada penentuan peserta didik, adapun penentuan sampel pada murid terlebih dahulu dari 2 kelas yang telah dibentuk oleh pihak sekolah, peneliti merancang kelas tersebut menjadi 2 kelompok, dari 2 kelompok itu dipilihlah sampel secara acak. Penentuan sampel yaitu murid kelas IV A dan B yang keseluruhan berjumlah 52 orang dari banyaknya jumlah populasi. Dari kedua kelas tersebut, untuk menentukan kelas eksperimen dan kelas kontrol dilakukan dengan cara random (acak), dilihat dari semua murid di kelas A dan B dipakai dalam penelitian maka hal ini dinamakan purposif sampling.

Data yang diperoleh dari sampel penelitian berupa data kuantitatif. Data tersebut dianalisis dengan statistika deskriptif dan teknik analisis statistik infrensial. Statistika deskriptif adalah statistika yang berfungsi mendeskripsikan atau memberikan gambaran terhadap objek yang diteliti melalui data sampel atau populasi sebagaimana adanya, tanpa melakukan analisis dan membuat kesimpulan yang berlaku untuk umum. (Sugiyono, 2010: 207)

\section{HASIL DAN PEMBAHASAN}

\section{Gambaran hasil belajar Matematika murid SD Inpres BTN IKIP 1 Makassar}

Hasil belajar Matematika diukur menggunakan instrumen berupa tes hasil belajar (soal) yang berjumlah dua puluh item pertanyaan. Sebelum tes hasil belajar diberikan pada kelas eksperimen dan kontrol terlebih dahulu divalidasi oleh ahli materi dan pembelajaran. Dalam hal ini yang menjadi validator ahli hasil belajar. Selanjutnya diberikan kepada 20 responden diluar sampel penelitian dan diperolelah lima belas item tes hasil belajar yang valid, dapat diliat pada lampiran.

Setelah instrumen tes hasil belajar diujikan diperoleh data pretest dan data posttest sebagai berikut.

Tabel 4.1 gambaran hasil belajar siswa sebelum dan sesudah perlakuan

\begin{tabular}{|c|c|c|c|c|c|c|c|c|c|}
\hline \multicolumn{4}{|c|}{ Kelompok eksperimen } & \multirow{3}{*}{ Interval } & \multirow{3}{*}{ Kategori } & \multicolumn{4}{|c|}{ Kelompok control } \\
\hline \multicolumn{2}{|c|}{ Pretest } & \multicolumn{2}{|c|}{ Posttest } & & & \multicolumn{2}{|c|}{ Pretest } & \multicolumn{2}{|c|}{ Posttest } \\
\hline$F$ & $\%$ & $f$ & $\%$ & & & $\bar{f}$ & $\%$ & $f$ & $\%$ \\
\hline
\end{tabular}




\begin{tabular}{|c|c|c|c|c|c|c|c|c|c|}
\hline 0 & 0 & 14 & 53,85 & $86-100$ & Sangat tinggi & 0 & 0 & 2 & 7,69 \\
\hline 1 & 3,85 & 7 & 26,92 & $71-85$ & Tinggi & 2 & 7,69 & 4 & 15,38 \\
\hline 5 & 19,23 & 5 & 19,23 & $56-70$ & Sedang & 6 & 23,08 & 8 & 30,77 \\
\hline 8 & 30,77 & 0 & 0 & $41-55$ & Rendah & 7 & 26,92 & 10 & 38,46 \\
\hline 12 & 46,15 & 0 & 0 & $<40$ & Sangat rendah & 11 & 42,31 & 2 & 7,69 \\
\hline 26 & 100 & 26 & 100 & \multicolumn{2}{|c|}{ Jumlah } & 26 & 100 & 26 & 100 \\
\hline
\end{tabular}

Sumber : Data Primer Hasil Penelitian, 2017

\section{a. Gambaran Hasil Belajar Siswa Sebelum Diberi Perlakuan pendekatan kontekstual}

Tabel 4.1 menunjukkan bahwa pada kelompok eksperimen sebelum diberikan perlakuan pendekatan kontekstual, hasil belajar di SD Inpres BTN IKIP 1 Makassar sebanyak 1 orang siswa pada kategori tinggi dengan persentase $3,85 \%$, pada sedang sebanyak 5 orang anak dengan persentase 19,23\%, pada kategori rendah sebanyak 8 orang anak dengan persentase $30,77 \%$ dan pada kategori sangat rendah sebanyak 12 orang anak dengan persentase $46,15 \%$. Sedangkan pada kelompok kontrol sebelum pembelajaran (pretest) hasil belajar di SD Inpres BTN IKIP 1 Makassar sebanyak 2 orang siswa pada kategori tinggi dengan persentase $7,69 \%$, pada kategori sedang sebanyak 6 orang anak dengan persentase $23,08 \%$, pada kategori rendah sebanyak 7 orang anak dengan persentase 26,92\% dan pada kategori sangat rendah sebanyak 11 orang anak dengan persentase $42,31 \%$.

Pretest dilakukan pada kelas eksperimen dan kontrol untuk mengetahui hasil belajar terhadap pembelajaran Matematika. Berdasarkan hasil analisis terhadap data nilai pretest menunjukkan bahwa kelas eksperimen dan kontrol memiliki kemampuan awal yang tidak berbeda secara signifikan. Hasil pretest kedua kelas memiliki rata-rata yang kecil dan termasuk kualifikasi rendah dan sangat rendah. Hal ini menunjukkan bahwa hasil belajar kelompok eksperimen dan kelompok kontrol sebelum mengikuti pembelajaran rendah.

\section{b. Gambaran hasil siswa sesudah diberi perlakuan}

Kuesioner hasil belajar untuk posttest sama dengan pretest. Hal itu agar tidak terjadi bias antara pretest dan posttest. Kuesioner hasil belajar untuk posttest berjumlah 15 item pernyataan yang memiliki rentang nilai 0-100. Skor hasil siswa yang diajarkan dengan menggunakan pendekatan kontekstual (kelompok eksperimen) diperoleh skor tertinggi adalah 100 dan terendah adalah 60 . Siswa yang diajarkan dengan metode ceramah (kelas kontrol) memiliki skor tertinggi adalah 80 dan terendah adalah 33 .

Setelah diberikan perlakuan pendekatan kontekstual, hasil belajar siswa mengalami peningkatan. Pada kategori sangat tinggi terdapat 14 orang siswa dengan nilai persentase $53,85 \%$, pada kategori tinggi terdapat 7 orang siswa dengan nilai persentase $26,92 \%$, pada kategori sedang terdapat 5 orang siswa dengan nilai persentase 19,23\%. Sedangkan pada kelompok kontrol Pada kategori sangat tinggi terdapat 2 orang siswa dengan nilai persentase $7,69 \%$, pada kategori tinggi terdapat 4 orang siswa dengan nilai persentase $15,38 \%$, pada kategori sedang terdapat 8 orang siswa dengan nilai persentase $30,77 \%$, pada kategori rendah terdapat 10 orang siswa dengan nilai persentase $38,46 \%$ dan sangat rendah terdapat 2 orang siswa dengan nilai persentase $7,69 \%$.

Hal tersebut menunjukkan bahwa hasil belajar siswa kelas eksperimen mengalami peningkatan yang besar jika dibandingkan dengan saat pretest. Rendahnya hasil belajar siswa pada kelas kontrol ini disebabkan kurang tepatnya pemilihan metode pembelajaran yang digunakan untuk hasil siswa.

Hasil posttest siswa kelas eksperimen mengalami peningkatan yang lebih baik, yaitu dari kualifikasi rendah menjadi tinggi. Tingginya nilai posttest siswa terjadi akibat model pembelajaran yang digunakan pendekatan kontekstual dapat meningkatkan kemapuan bekerjasama siswa dalam pembelajaran matematika. Hal itu dikarenakan 
terjadi pembelajaran yang menyenangkan dan melibatkan semua siswa dalam kegiatan pembelajaran.

Saat guru menggunakan pendekatan kontekstual, siswa mengikutinya dengan baik. Pembelajaran berjalan sesuai dengan langkahlangkah pendekatan kontekstual, yaitu: Konstruktivisme; inquiri (menemukan), questioning (bertanya), learning community (masyarakat belajar), modeling (pemodelan), reflection (refleksi), authentic assessment (penilaian sebenarnya).

Berdasarkan rata-rata nilai kelas eksperimen dan kontrol diperoleh selisih sebesar 24,11 $(83,23-59,12=24,11)$, dengan kelas eksperimen di atas kelas kontrol. Perbedaan rata-rata tersebut menunjukkan bahwa pendekatan kontekstual berpengaruh untuk meningkatkan hasil belajar.

Berdasarkan uarian di atas dapat disimpulkan bahwa hasil belajar siswa pada kelompok eksperimen lebih tinggi daripada kelompok kontrol. Jika dilihat dari rata-rata pretest kelas kontrol dan eksperimen memiliki nilai yang hampir sama, namun hasil posttest menunjukkan kelas eksperimen lebih baik dibanding kelas kontrol. Hal ini mengindikasikan bahwa penggunaan pendekatan kontekstual berpengaruh lebih baik untuk meningkatkan hasil belajar siswa terhadap pembelajaran matematika daripada kelas kontrol yang menggunakan metode ceramah.

Jika dibandingkan data hasil belajar siswa yang diberikan penerapan pendekatan kontekstual pada mata matematika murid SD Inpres BTN IKIP 1 Makassar dengan hasil belajar siswa yang tidak diberikan penerapan pendekatan kontekstual menunjukan keunggulan pada kelas eksperimen yang tidak ada lagi siswa memiliki hasil belajar rendah dan sangat rendah sedangkan pada kelas kotrol masih ada siswa yang berada pada kategori tersebut. Hal ini membuktikan bahwa pendekatan pembelajaran yang baik, pada dasarnya tergantung kebutuhan guru. Sebaiknya sesuai dengan materi yang akan diberikan pada waktu itu, pendekatan yang baik, sebaiknya mampu membuat siswa aktif dalam proses pembelajaran bukan sebaliknya. Pemilihan pendekatan sebaiknya mengacu kepada kebutuhan peserta didik guna mempermudah proses belajar siswa. Menurut Elaine B. Johnson (2007:19) pendekatan pembelajaran merupakan kegiatan yang dipilih yang dapat memberikan fasilitas atau bantuan kepada peserta didik untuk mencapai tujuan pembelajaran.

Ada tujuh komponen utama pendekatan kontekstual yang terdiri atas: “(a) komponen konstruktivisme, (b) komponen inkuiri, (c) komponen bertanya, (d) komponen masyarakat belajar, (e) komponen pemodelan, (f) komponen refleksi, dan (g) komponen penilaian”, (Nurhadi, 2003: 3).

Pelaksanaan pembelajaran dengan menggunakan pendekatan kontekstual dalam penelitian ini dipilih karena dipandang dapat mengoptimalkan interaksi semua unsur pembelajaran. Hal ini terlihat dari upaya yang dilakukan guru untuk meningkatkan pemahaman terhadap materi operasi hitung bilangan adalah terlebih dahulu mengecek pemahaman siswa tentang materi tersebut. Tetapi kenyataannya hampir seluruh siswa belum memahami materi tersebut, oleh karena itu peneliti lebih dulu memberikan pemahaman tentang materi operasi hitung bilangan.

Dengan mengecek materi prasyarat dapat menjadikan dasar atau landasan guru dalam memberikan tindakan dalam penelitian ini. Hal ini sejalan dengan salah satu ciri pembelajaran dengan pendekatan kontekstual yaitu "pengetahuan prasyarat merupakan pengalaman awal peserta didik dan situasi pengetahuan yang didapat mereka akan berarti atau bernilai dan nampak sebagai dasar dalam pembelajaran", (Aisyah, 2006: 11).

Berdasarkan uraian diatas jelaslah sudah bahwa dengan menggunakan pendekatan Contextual Teaching and Learning (CTL) dapat meningkatkan pemahaman siswa dalam pembelajaran matematika khususnya pada materi operasi hitung bilangan. Dimana materi yang abstrak dalam penelitian ini dapat disajikan secara konkret karena siswa membangun pengetahuan dalam benaknya sendiri melalui pengalaman nyata. Hal ini sesuai dengan yang diungkapkan oleh landasan filosofi konstruktivisme bahwa "melalui pendekatan kontekstual siswa diharapkan belajar melalui mengalami bukan menghafal" 
(Nurhadi, 2003: 9). Oleh karena itu pendekatan CTL memungkinkan untuk dijadikan sebagai salah satu model pembelajaran dalam meningkatkan prestasi siswa dalam pembelajaran matematika khususnya di SD.

\section{SIMPULAN}

Berdasarkan rumusan masalah, tujuan penelitian, dan hasil yang diperoleh sebagaimana yang telah diuraikan pada bab sebelumnya, maka pada bagian ini disajikan kesimpulan sebagai implikasi dari hasil yang diperoleh. Adapun kesimpulan (i) Hasil belajar siswa dalam pembelajaran Matematika di kelas V SD Inpres BTN IKIP 1 Makassar sebelum penerapan pendekatan kontekstual berada pada kategori sangat rendah, setelah penerapan pendekatan kontekstual berada pada kategori sangat tinggi. Sedangkan pada kelompok kontrol berada pada kategori sangat rendah ke kategori rendah (ii) Penerapan pendekatan kontekstual yang terdiri dari tahap konstruktivisme, inquiri (menemukan), questioning (bertanya), learning community (masyarakat belajar), modeling (pemodelan), reflection (refleksi), authentic assessment (penilaian sebenarnya) pada umumnya terlaksana dengan baik berdasarkan hasil dan pelaksanaannya (iii) Penerapan pendekatan kontekstual berpengaruh terhadap hasil belajar pada mata pelajaran Matematika siswa kelas V SDN KIP Maccini Kecamatan Makassar Kota Makassar.

\section{Saran}

Sesuai dengan kesimpulan tersebut, maka dapat diajukan beberapa saran sebagai berikut:

1. Bagi guru diharapkan agar menerapkan pendekatan kontekstual sebagai alternatif model pembelajaran untuk meningkatkan hasil belajar siswa.

2. Kepala sekolah hendaknya berperan sebagai inisiator agar guru menggunakan Penerapan pendekatan kontekstual pada pembelajaran matematika.

3. Bagi peneliti selanjutnya, khususnya yang berkecimpung dalam pendidikan dasar, penelitian yang dilakukan dalam studi ini, hanya mengungkapkan salah satu penerapan model pembelajaran saja yang ada kaitannya dengan hasil belajar siswa, dan masih banyak lagi model-model lain yang belum diungkapkan dalam penelitian ini. Untuk itu disarankan bagi peneliti yang berhasil untuk melakukan kajian lebih lanjut dan lebih mendalam.

\section{DAFTAR RUJUKAN}

Elaine B. Johnson, PH.D. (2007). Contextual Teaching and Learning. Bandung: MLC.

Hamzah B. Uno dan Satria Koni, 2012. Assesmen Pembelajaran. Jakarta: Bumi Aksara

Hamruni. 2011. Strategi Belajar Mengajar. Bandung : Pustaka Setia.

Karso. (2007). Pendidikan Matematika I. Jakarta: Universitas Terbuka.

Nana Sudjana. 2013. Penilaian Hasil Proses Belajar Mengajar, Bandung: PT. Remaja Rosdakarya.

Sugiyono.(2010). MetodePenelitian Kuantitatif Kualitatif \& RND. Bandung : Alfabeta.

Tim MKPBM. (2001). Strategi Pembelajaran Matematika Kontemporer. Bandung: Jurusan Pendidikan Matematika FPMIPA UPI

Yusuf, A Muri.2014. Metode Penelitian Kuantitatif Kualitatif dan Penelitian. Prenadamedia Group. Jakarta. 